\title{
Biochemical characterization of four different genotypes of Flax (Linum usitatissimum L.) seeds
}

\author{
Gökhan SADİ ${ }^{1 *}$, Burhan KARABAKAN ${ }^{1}$, Muhammad AASIM ${ }^{2}$ \\ ${ }^{1}$ Karamanoglu Mehmetbey University, K.Ö. Science Faculty, Department of Biology, Karaman, Turkey \\ ${ }^{2}$ Necmettin Erbakan University, Science Faculty, Department of Biotechnology, Konya, Turkey \\ *sadi.gokhan@gmail.com
}

\section{Dört farklı genotipe sahip keten (Linum usitatissimum L.) tohumlarının biyokimyasal karakterizasyonu}

\begin{abstract}
Flaxseed (Linum usitatissimum L.) is an oilseed used in industrial and natural health products. It accumulates many biologically active compounds having strong phytochemicals and antioxidant properties. This study aims to provide an entire portfolio of bioactive compounds present in four different genotypes of flaxseed (Avangard, Bony Doon, Linda and Linton). Biochemical diversity among these four different types of seed with respect to oxidant and antioxidant parameters (phenolics, flavonoids, $\beta$-karoten, lycopen, DPPH scavenging activity, MDA, proline, SOD, CAT, APx and GR) were investigated. According to results, Linda types are found to have unusual phytochemicals and antioxidant profile since its oxidative status tends to the production of oxidant molecules which was reflected in differences in radical scavenging, MDA and antioxidant enzyme systems. Other flaxseeds demonstrate noticeable activities with their antioxidant potential together with their high phytochemicals. Therefore, they may be utilized as a promising source of therapeutics since they might provide an appropriate source of antioxidants.
\end{abstract}

Key words: Flaxseed, Phytochemicals, Bioactive compounds, Antioxidant enzymes

Özet: Keten (Linum usitatissimum L.) tohumları, endüstri ve doğal sağlık ürünleri alanında kullanılan yağlı tohumlardır. Biyolojik olarak aktif pek çok fitokimyasal ve antioksidan özelliklere sahip maddeyi yapılarında bulundurabilirler. Bu çalışma, dört farklı genotipteki keten tohumlarının (Avangard, Bony Doon, Linda ve Linton) biyoaktif içeriklerinin araştıılmasını ve özetlenmesini hedeflemiştir. Buna nedenle oksidan ve antioksidan parametrelerinin (fenolikler, flavonoidler, $\beta$-karoten, likopen, DPPH radikal yakalama aktivitesi, MDA, prolin, SOD, CAT, APx ve GR) dört farklı keten tohumundaki biyokimyasal çeşitliliği araştırılmıştır. Sonuçlara göre Linda türü keten tohumlarının diğer çeşitlere oranla beklenmedik bir şekilde farklı fitokimyasal ve antioksidan profiline sahip olduğu, bu tohumların oksidatif durumlarının oksidan molekülleri üretmeye eğilimli olduğu DPPH radikal yakalama, MDA ve antioksidan enzim aktivite sonuçlarına göre belirlenmiştir. Ayrıca diğer keten tohumlarının fark edilebilir şekilde yüksek oranda antioksidan ve fitokimyasal potansiyele sahip oldukları gösterilmiștir. Bu nedenle terapötik olarak önemli özellikleri ve antioksidan içerik açısından zengin olmaları nedeniyle keten tohumlarından daha fazla faydalanılmalıdır.

Anahtar Kelimeler: Keten tohumu, Fitokimyasallar, Biyoaktif bileşikler, Antioksidan enzimler

\section{Introduction}

Potential plant-derived agents that would influence human health have been in the focus of recent researches. Since ancient times, the biological activities of plants producing a wide range of phytochemicals have been known. One of the possible source of such bioactive compounds is flax (Linum usitatissimum), which is widely distributed in Mediterranean and temperate climate zone. The seeds of this plant have been demonstrated to have considerable functions in pharmaceutical and food industry (Czemplik et al., 2012). Even though main well-known beneficial properties are generally linked with its oil composition, ample of bioactive phytochemicals are also present in their seeds (Goyal et al., 2014).

Antioxidants are the compounds functioning in the neutralization of free radicals and therefore a healthy organism should have enough antioxidant ingredients to protect its functionality. Due to their antioxidant properties, flax seeds have been linked to the prevention and treatment of hypercholesterolemia, diarrhea, cardiovascular disorders, diabetes and certain types of cancers especially breast and colon cancers (Prasad, 2000, 2009; Wang et al., 2005; Amawi et al., 2017). However, considering the huge genetic variations in different genotypes of this plant in Turkey, there were a few reports about the phytochemical comparison of different genotypes of flaxseed cultivated in different areas of Mediterranean region.

This study focused on the analysis of bioactive features of four different genotypes of flaxseed which are Avangard, Bony Doon, Linda and Linton type. In this concern, we elucidated the biochemical diversity with respect to enzymatic and non-enzymatic antioxidant systems. Accordingly, amount of phenolics, flavonoids, $\beta$-karoten, lycopen, DPPH scavenging activity, MDA and proline contents were evaluated with biochemical assays together with activities of main antioxidant enzymes which are superoxide dismutase (SOD), catalase (CAT), ascorbate peroxidase (APx) and glutathione reductase (GR)..

\section{Materials and Method}

Four different genotypes of naturally growing flaxseeds; Avangard, Bony Doon, Linda and Linton were kindly provided by Dr. Sibel Day from Ankara University. Before biochemical characterization, seeds were powdered with liquid nitrogen, mortar and paste. Then, the prepared samples were used for the homogenization. They were homogenized in homogenization solution $(50 \mathrm{mM}$ $\mathrm{KH}_{2} \mathrm{PO}_{4}, 5 \mathrm{mM}$ EDTA, \%1.15 KCI, \%2 PVP, pH 7.4) with 
Ultraturrax $^{\mathrm{TM}}$ homogenizator and then centrifuged at $9,000 \mathrm{~g}$ for $10 \mathrm{~min}$ at $+4^{\circ} \mathrm{C}$. Afterwards, supernatants were collected, their total protein contents were measured (Lowry et al., 1951) and then stored at $-85^{\circ} \mathrm{C}$ until used.

\section{Total phenolic contents}

Total amount of phenolic compounds in homogenates of four different flaxseeds were determined spectrophotometrically according to method previously described (Taga et al., 1984) with slight modifications. Gallic acid with various concentrations (0.01-1.0 mM) was used as standard phenolic compound. Briefly, $20 \mu \mathrm{l}$ of standards or homogenates of seeds $(10 \mathrm{mg} / \mathrm{ml})$ were mixed with same amount of Folin and Ciocalteu's phenol reagent $(2 \mathrm{~N})$ and kept at dark for $3 \mathrm{~min}$. Then, $20 \mu \mathrm{l}$ of $35 \%$ sodium carbonate $(\mathrm{w} / \mathrm{v})$ and $140 \mu 1 \mathrm{dH}_{2} \mathrm{O}$ were added and incubated for $10 \mathrm{~min}$. Next, absorbance values were measured at $725 \mathrm{~nm}$ and the results were calculated as mean \pm standard error of mean (SEM) from gallic acid calibration curve and expressed as $\mathrm{mg}$ of gallic acid equivalents per $\mathrm{mg}$ of protein containing homogenates.

\section{Total flavonoid contents}

Total flavonoid contents of flaxseeds were determined using protocol (Pal et al., 2010) with slight modifications. Simply, $50 \mu \mathrm{l}$ of homogenates $(10 \mathrm{mg} / \mathrm{ml})$ were mixed with $215 \mu \mathrm{l}$ of ethanol $(80 \% \mathrm{v} / \mathrm{v}), 5 \mu \mathrm{l}$ of aluminium nitrate $(10 \% \mathrm{w} / \mathrm{v})$ and $5 \mu \mathrm{l}$ potassium acetate $(1 \mathrm{M})$ in microtiter plates and incubated for $40 \mathrm{~min}$ at room temperature. Absorbance values were recorded at $415 \mathrm{~nm}$. Total flavonoid contents were calculated according to following formula; Total flavonoid contents $(\mu \mathrm{g} / \mathrm{mg}$ protein $)=\left(\mathrm{A}_{415}+0.01089\right) / 0.002108$

\section{$\beta$-Carotene and lycopene contents}

In order to determine $\beta$-carotene and lycopene contents, homogenates of four different flaxseeds were re-extracted with equal amount of acetone:hexane (4:6) mixture and filtered through Whatman No.4 filter paper. After reextraction process, absorbance of the filtrates was measured at 453, 505 and $663 \mathrm{~nm}$. $\beta$-carotene and lycopene contents were determined according to following equations (Pal et al., 2010).

$\beta$-carotene content $(\mathrm{mg} / 100 \mathrm{mg})=0.216 \mathrm{~A}_{663}-0.304 \mathrm{~A}_{505}$ $+0.452 \mathrm{~A}_{453}$

Lycopene content $(\mathrm{mg} / 100 \mathrm{mg})=-0.0458 \mathrm{~A}_{663}+$ $0.372 \mathrm{~A}_{505}-0.0806 \mathrm{~A}_{453}$

\section{Radical (DPPH) scavenging activity}

Free radical scavenging activities of seeds were determined by monitoring 2,2-diphenyl-1-picrylhydrazyl (DPPH) reduction. Gallic acid $(0.01-0.10 \mathrm{mM})$ was used as standard antioxidant molecule. In brief, $20 \mu 1$ of various concentrations of standards or homogenates containing different amount of protein $(0.1,0.2,0.25,0.33,0.5,1.0$, $2.0,5.0 \mathrm{mg} / \mathrm{ml})$ were mixed with $180 \mu \mathrm{l}$ of DPPH $(0.06$ $\mathrm{mM}$ in methanol) and incubated for $1 \mathrm{~h}$ at dark in microtiter plates. Blank measurements were also performed without standards or homogenates. Reduction of DPPH radical was determined after reading absorbance at $517 \mathrm{~nm}$, as percent discoloration of DPPH. Protein concentration providing $50 \%$ inhibition $\left(\mathrm{IC}_{50}\right)$ was calculated from the graph of RSA vs. protein amount (Turkoglu et al., 2007).

\section{Malonedialdehyde (MDA) contents}

MDA contents of flaxseeds were evaluated after homogenization of $0.1 \mathrm{gr}$ of fresh seeds in $5 \%$ of trichloroasetic acid (TCA) solution and centrifugation at $12,000 \mathrm{~g}$ for $15 \mathrm{~min}$. Equal amounts of $0.5 \%$ thiobarbutiric acid (TBA) which was prepared in $20 \%$ TCA was added to homogenates and incubated at $100^{\circ} \mathrm{C}$ for $25 \mathrm{~min}$. After incubation, samples were chilled on ice and centrifuged at $10,000 \mathrm{~g}$ for $5 \mathrm{~min}$. Then, absorbance of supernatants were determined at 532 and $600 \mathrm{~nm}$. MDA contents were calculated by using extinction coefficient of MDA (155 $\left.\mathrm{mM}^{-1} . \mathrm{cm}^{-1}\right)$ (Savicka and Skute, 2010).

\section{Proline contents}

Proline contents of homogenates were determined after homogenization of $0.2 \mathrm{gr}$ of seeds in $2 \mathrm{ml}$ of $3 \%$ sulfosalisylic acid and centrifugation at $14,000 \mathrm{~g}$ for 5 min. Hundred microliter of supernatant were added onto a solution containing $0.2 \mathrm{ml}$ of ninhydrin solution $(0.31 \mathrm{~g}$ ninhydrin, $7.5 \mathrm{ml}$ asetic asid, $5 \mathrm{ml} 6 \mathrm{M}$ fosforic asid), 0.2 $\mathrm{ml}$ of phosphoric acid and $0.1 \mathrm{ml}$ of $3 \%$ sulfosalisylic acid. This mixture was then incubated at $96^{\circ} \mathrm{C}$ for 1 hour and then $1 \mathrm{ml}$ of toluene was added. The absorbance of upper phase was determined at $520 \mathrm{~nm}$. Standard calibration curve obtained with proline standards $(0.01$ $\mathrm{mM}-1.5 \mathrm{mM}$ ) was used to calculate prolin contents of flaxseeds (Ábrahám et al., 2010).

\section{Catalase (CAT) activity}

The decomposition of hydrogen peroxide $\left(\mathrm{H}_{2} \mathrm{O}_{2}\right)$ was followed directly by the decrease in absorbance at $240 \mathrm{~nm}$ and the difference in absorbance per unit time was the measure of CAT activity (Aebi, 1984). According to modified method, $240 \mu 1$ of phosphate buffer $(50 \mathrm{mM}, \mathrm{pH}$ : $7.0), 10 \mu \mathrm{l}$ of homogenates $(0.5 \mathrm{mg} / \mathrm{ml})$ and $50 \mu 1$ of $\mathrm{H}_{2} \mathrm{O}_{2}$ $(50 \mathrm{mM})$ were mixed in UV transparent 96 well plate and the change in absorbance was monitored at $240 \mathrm{~nm}$. One unit of CAT activity was defined as the amount of substrate consumed in $1 \mathrm{~min}$ by $1 \mathrm{mg}$ total protein containing homogenate.

\section{Total superoxide dismutase (SOD) activity}

Total SOD activities were measured by following the inhibition of pyrogallol autoxidation spectrophotometrically (Marklund and Marklund, 1974). According to method, $250 \mu \mathrm{l}$ of Tris buffer $(50 \mathrm{mM}$ Tris, $10 \mathrm{mM}$ EDTA, pH: 8.2) were mixed with $30 \mu 1$ pyrogallol solution $(20 \mathrm{mM})$ and different amount of homogenates in 96 well plates and the rate of adduct formation were followed at $440 \mathrm{~nm}$. One unit of SOD activity was calculated as the amount of protein causing $50 \%$ inhibition of pyrogallol autoxidation.

\section{Glutathione reductase (GR) activity}

GR activities of seed homogenates were determined with a method we have modified (Foster and Hess, 1980) for the microplate measurements. In this method, $225 \mu 1$ phosphate buffer $\left(150 \mathrm{mM} \mathrm{K} \mathrm{HPO}_{4}, 25 \mathrm{mM}\right.$ EDTA, pH: $7.8), 25 \mu 1$ of homogenate $(5 \mathrm{mg} / \mathrm{ml}), 25 \mu \mathrm{l}$ of NADPH $(2.5 \mathrm{mM})$ and $25 \mu \mathrm{l}$ of oxidized glutathione $(6 \mathrm{mM})$ were mixed in UV transparent 96 well plate and the decrease in absorbance at $340 \mathrm{~nm}$ were followed for 2 minutes. GR activity were calculated as the amount of NADPH $\left(\varepsilon_{340}=\right.$ 
$6.22 \mathrm{mM}^{-1} . \mathrm{cm}^{-1}$ ) oxidized in one minute with one $\mathrm{mg}$ protein containing seed homogenates.

\section{Ascorbate peroxidase (APx) activity}

APx activities of seed homogenates were determined according to a method (Sairam and Saxena, 2000) we have modified. Accordingly, $50 \mu \mathrm{l}$ of homogenates $(1 \mathrm{mg} / \mathrm{ml})$, $100 \mu \mathrm{l}$ of phospate buffer $\left(100 \mathrm{mM} \mathrm{K}_{2} \mathrm{HPO}_{4}, \mathrm{pH}\right.$ : 6.6) and $10 \mu \mathrm{l}$ of ascorbate solution $(1.5 \mathrm{mM})$ were mixed in UV transparent microplate wells and enzymatic reaction was initiated with the addition of $50 \mu \mathrm{l}$ of $\mathrm{H}_{2} \mathrm{O}_{2}(5 \mathrm{mM})$. The change in the absorbance was followed at $290 \mathrm{~nm}$ and the APx activity was calculated as the amount of ascorbate oxidized in one minute with one $\mathrm{mg}$ protein containing seed homogenates.

\section{Statistical analyses}

All the assays were carried out at least in triplicate measurements. The results are expressed as mean values and standard error of mean (SEM). Antioxidant activities of flaxseeds were analyzed using one way variance (ANOVA) test followed by appropriate post-hoc test (Tukey Test) and values with $p<0.05$ were considered as statistically significant. $\mathrm{IC}_{50}$ values were calculated with Lineer Regression Analysis and associated 95\% confidence limits for each treatment were determined. For all those statistical calculations GraphPad Prism 6.0 software were utilized.

\section{Results and Discussion}

Antioxidants are vital molecules which protect the living organism from the deleterious effects of oxidation. The inhibition or retention of oxidation prevents the possible structural protein or DNA damages caused by reactive oxygen species which are produced by several reactions in living systems (Maity et al., 2014). As being vital in particular conditions for the maintenance of the life, antioxidants have been studied by so many researchers. Presence of natural antioxidant molecules in nutraceuticals; especially plant origin are of considerable interest since they have imperative constituents with free radical scavenging and contribute to antioxidative reactions directly. Among them; phenolic compounds, flavonoids, $\beta$-carotene and lycopene contents correlates well with the antioxidant potential. In the present study, biological contents of four different genotypes of flaxseeds were investigated to elucidate their potential for nutritional and therapeutic use and the results are summarized in Figure 1.

According to results, Linda type of flaxseed has the lowest protein content as compared to the other seeds (Figure 1A). Moreover, it has the lowest radical scavenging activity $\left(\mathrm{IC}_{50}: 0.0096 \mathrm{mg} / \mathrm{ml}\right.$ ) (Figure 1B). Highest DPPH radical scavenging were obtained from seeds in the order of Bony Doon ( $\mathrm{IC}_{50}$ : $0.0047 \mathrm{mg} / \mathrm{ml}$ ), Avangard ( $\mathrm{IC}_{50}$ : $0.0057 \mathrm{mg} / \mathrm{ml}$ ) and Linton ( $\left.\mathrm{IC}_{50}: 0.0059 \mathrm{mg} / \mathrm{ml}\right)$. In parallel with the radical scavenging activity, the main indicator of the free radical induced oxidative stress; MDA levels were also determined to be highest in Linda type flaxseeds $(3.096 \pm 0.034 \mu \mathrm{M} / \mathrm{mg})$ indicating the low antioxidant potential which leads to oxidatively modified products to be accumulated (Figure 1C). MDA contents of Linton, Avangard and B ony Doon types were significantly lower than that of Linda types. MDA levels has the order of Avangard> Bony Doon $>$ Linton $>$ Linda in different genotypes of flaxseeds. Figure 1D demonstrates that Linton type of seeds were the richest considering the proline contents $(0.321 \pm 0.019 \mathrm{mM} / \mathrm{mg})$ and Linda $(0.221 \pm 0.022 \mathrm{mM} / \mathrm{mg})$, Avangard $(0.193 \pm 0.019 \mathrm{mM} / \mathrm{mg})$ and Bony Doon $(0.118 \pm 0.012 \mathrm{mM} / \mathrm{mg})$ follows this genotype. On the contrary to these oxidative parameters, Linda type of seeds has the highest amount of phenolics and flavonoid content. It has $21.99 \pm 0.74 \mathrm{mM} \mathrm{GAE} / \mathrm{mg}$ of total phenolics but the others had approximately half of this value (13.90; 11.61 and $12.80 \mathrm{mM} \mathrm{GAE} / \mathrm{mg}$ ) (Figure 1E). In parallel with the phenolic contents, highest flavonoid $(9.51 \pm 0.34 \mathrm{mg} / \mathrm{mg})$ was also present in Linda types (Figure 1F). It is interesting to note that; amount of total phenolics and flavonoid was inversely proportional to $\beta$-carotene and lycopene contents. $\beta$-carotene $(11.65$ $\mathrm{mg} / 100 \mathrm{mg})$ and lycopene $(6.87 \mathrm{mg} / 100 \mathrm{mg})$ contents of Linda types of flaxseeds were as half of the other types (Figure $1 \mathrm{G}$ and $1 \mathrm{H}$ ). $\beta$-karoten contents of Linton $(20.16 \pm 2.56 \mathrm{mg} / 100 \mathrm{mg}), \quad$ Avanagard (20.22 \pm 1.01 $\mathrm{mg} / 100 \mathrm{mg})$ and Bony Doon $(21.04 \pm 0.39 \mathrm{mg} / 100 \mathrm{mg})$ were significantly higher $(\mathrm{p}<0.05)$ than Linda types. Similarly lycopene contents were two times higher. We may confer from the data that the differences in the scavenging ability order could be due to reduction in $\beta$-caroten and lycopen contents in the flaxseeds which may have roles in radical scavenging activity.

\section{Antioxidant enzyme activities in different genotypes of flaxseeds}

The major antioxidant enzymes are superoxide dismutase (SOD) isozymes; SOD-1 and SOD-2 which neutralizes superoxide radicals in cytoplasm and mitochondria, respectively. Other protective mechanisms against oxidative stress could be classified as CAT which catalyzes the decomposition of hydrogen peroxide to water, a function that is shared with APx in plants. Additionally, GR helps oxidative glutathione to be reduced back to the glutathione for the antioxidant activities at the expense of cellular NADPH. The levels of these key antioxidant enzymes reflects the physiological oxidative conditions of flaxseeds which are modulated with the changes in cellular redox status.

The activities of main detoxification enzyme for superoxide radical (SOD) was found to be highest in Linda types of seeds $(4.685 \pm 0.468 \mathrm{U} / \mathrm{mg})$ which are directly correlated well with the high MDA content and low DPPH scavenging activity (Figure 2A). Additionally, CAT activity has the lowest in Linda (Figure 2B).This status reflects the presence of oxidative conditions in Linda seeds. The lowest SOD activity was observed in Linton $(1.935 \pm 0.194 \mathrm{U} / \mathrm{mg})$ type which was statistically different $(\mathrm{p}<0.05)$ than the others. Avangard and Bony Doon had approximately the same SOD activities $(2.238 \pm 0.224$ and $2.543 \pm 0.254 \mathrm{U} / \mathrm{mg}$, respectively). Any difference were observed in APx activity (Figure 2C), while GR activities were highly diverse in different types of flaxseeds. Accordingly, highest GR activities were observed in Avangard (3.371 $\pm 0.282 \mathrm{mU} / \mathrm{mg}$ ) and Bony Doon $(2.438 \pm 0.398 \mathrm{mU} / \mathrm{mg})$ so as to Linton $(1.607 \pm 0.608$ $\mathrm{mU} / \mathrm{mg})$ and Linda $(1.241 \pm 0.289 \mathrm{mU} / \mathrm{mg})$ followed Avangard. 

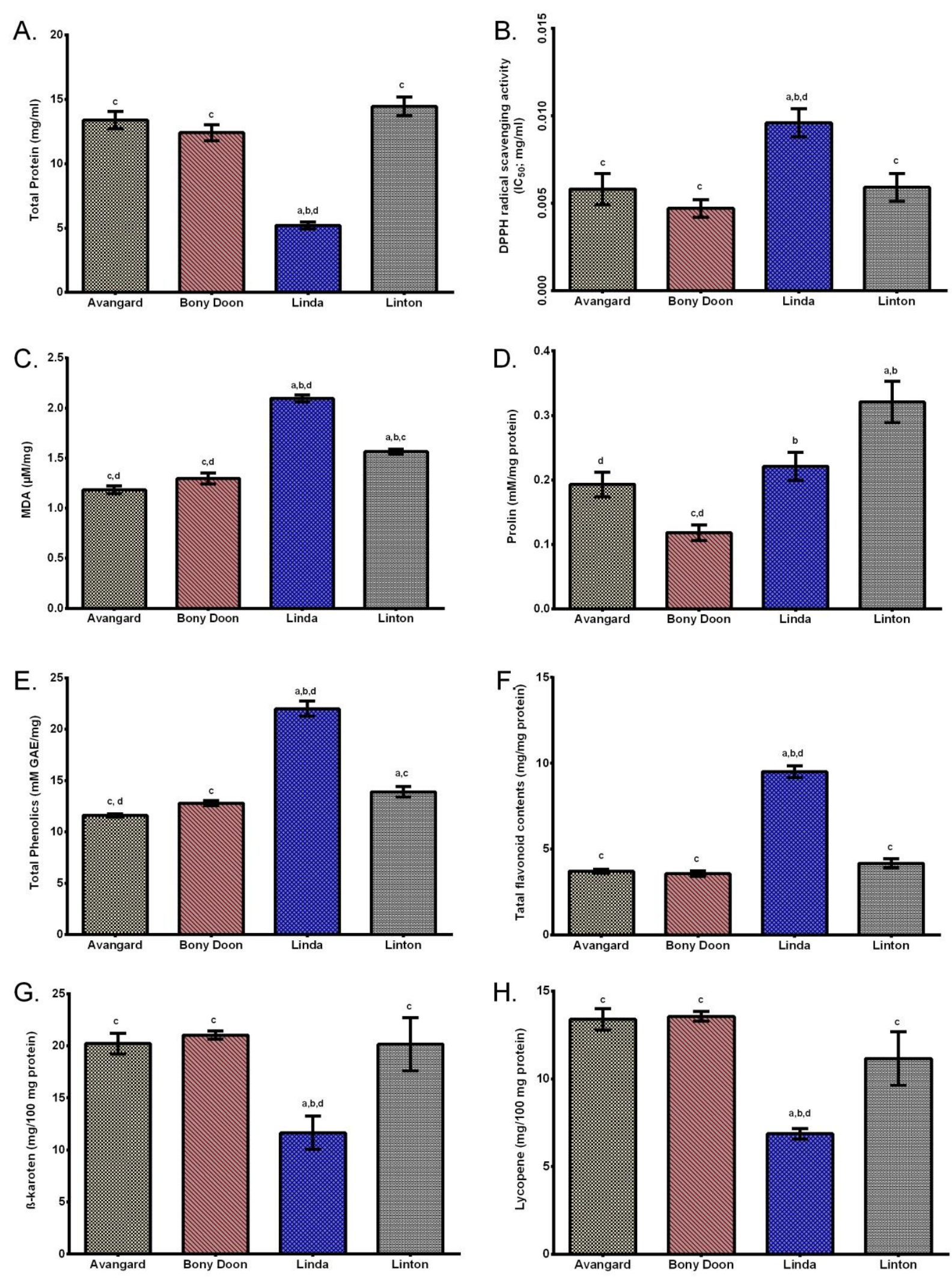

Figure 1: Antioxidant and oxidant potential of four different genotypes of flaxseeds. (A): Total protein content; (B): DPPH radical scavenging activity; (C): MDA content; (D): Prolin content; (E): Total phenolic contents; (F): Total flavonoid contents; (G) $\beta$-carotene contents; $(\mathrm{H})$ : lycopene contents of four different genotypes of flaxseeds. ${ }^{a}$ represents the significant differences as compared to Avangard $(\mathrm{P}<0.05) ;{ }^{b}$ represents the significant differences as compared to Bony Doon $(\mathrm{P}<0.05) ;{ }^{\mathrm{c}}$ represents the significant differences as compared to Linda $(\mathrm{P}<0.05)$; ); ${ }^{\mathrm{d}}$ represents the significant differences as compared to Linton $(\mathrm{P}<0.05)$. 
A

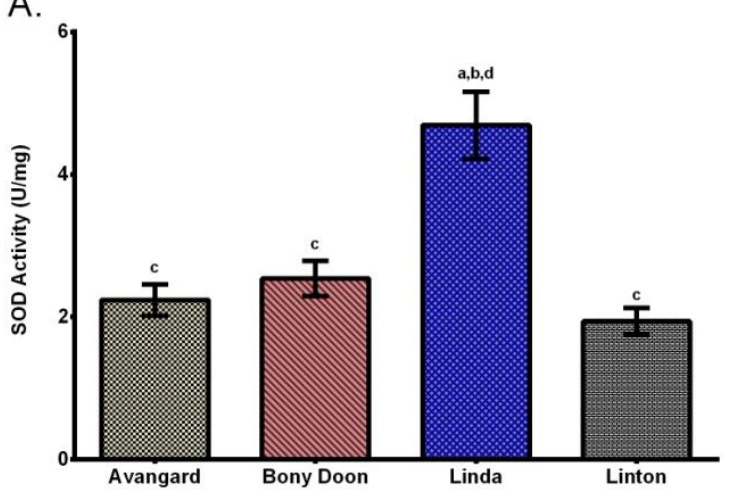

C

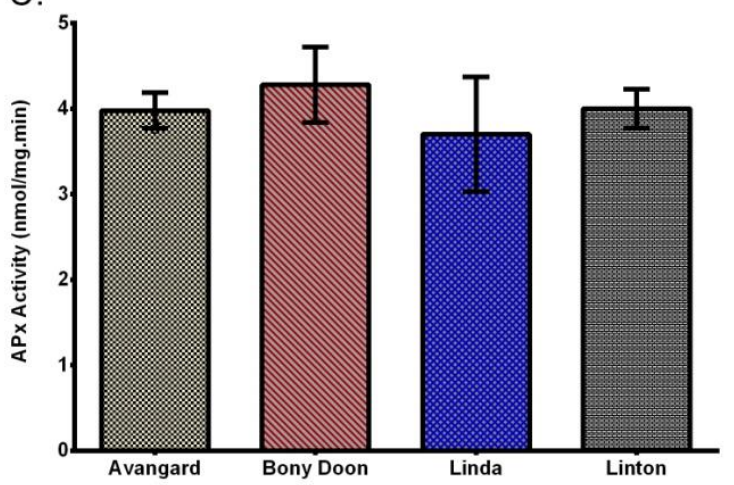

B.

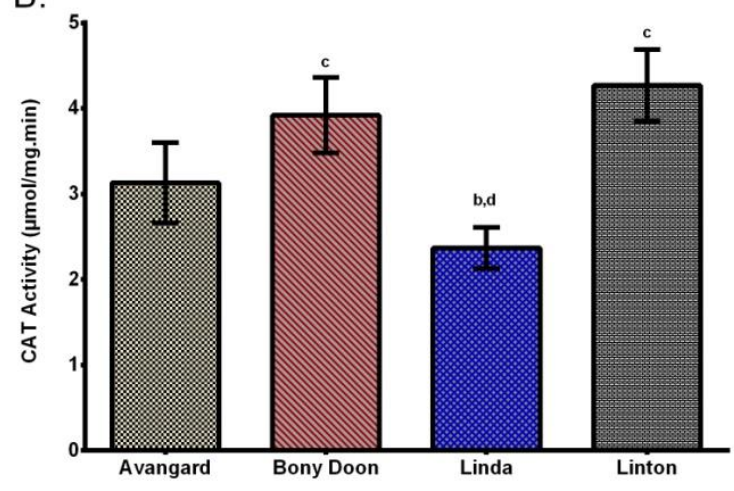

D.

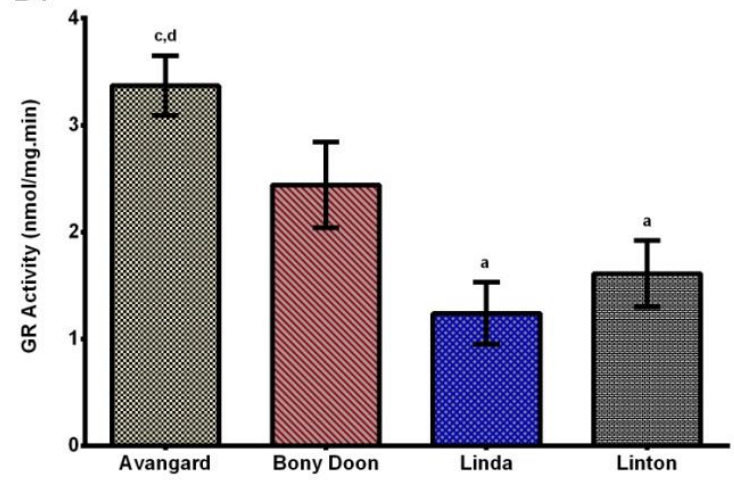

Figure 2: Antioxidant enzyme activities in four different genotypes of flaxseeds. (A): SOD activity; (B): CAT activity; (C): APx activity; (D): GR activity in different genotypes of flaxseeds. ${ }^{a}$ represents the significant differences as compared to Avangard (P<0.05); ${ }^{b}$ represents the significant differences as compared to Bony Doon $(\mathrm{P}<0.05)$; ${ }^{\mathrm{c}}$ represents the significant differences as compared to Linda $(\mathrm{P}<0.05)$; ${ }^{\mathrm{d}}$ represents the significant differences as compared to Linton $(\mathrm{P}<0.05)$.

The discrepancies in the enzymatic activities may be attributed to relative increase or decrease in enzyme activities as a compensatory mechanism to oxidative stress or direct inhibitory effects of free radicals or decrease in the total amount of antioxidant molecules in the system.

\section{Conclusion}

Flaxseed (Linum usitatissimum L.) has been the focus of interest of nutritionists due to potential health benefits. However, biochemical characterizations of all genotypes and their antioxidant efficacies have not been thoroughly documented. Further research in the context of in vitro and in vivo antioxidant potential of flaxseed is essential, as limited research attention has been received by them so far. In this article, an attempt was made to characterize antioxidant potential of four different genotypes of flaxseed; Avangard, Bony Doon, Linda, Linton. Linda types are found to have somewhat different phyto- chemicals and antioxidant profile since its oxidative status tends to the production of oxidant molecules which was reflected in differences in radical scavenging, MDA and antioxidant enzyme systems. Other flaxseeds demonstrate noticeable activities with their antioxidant potential together with their high phytochemicals. Therefore, they may be utilized as a promising source of therapeutics since they might provide an appropriate source of antioxidants.

\section{Acknowledgments}

This research was supported by Karamanoglu Mehmetbey University (07-M-15).

\section{Declaration of interest}

The authors have no conflicts of interest to disclose.

\section{References}

Ábrahám E, Hourton-Cabassa C, Erdei L, Szabados L (2010). Methods for Determination of Proline in Plants. In: Methods Mol. Biol. pp 317-331.

Aebi H (1984). In Methods in Enzymology. In: Catalase Vitr. Academy Press, NY, pp 121-126.

Amawi H, Ashby C, Samuel T, Peraman R, Tiwari AK (2017). Polyphenolic nutrients in cancer chemoprevention and metastasis:

Role of the epithelial-to-mesenchymal (EMT) pathway. Nutrients 9(8): 911. 
Czemplik M, Kulma A, Bazela K, Szopa J (2012). The biomedical potential of genetically modified flax seeds overexpressing the glucosyltransferase gene. BMC Complement Altern Med 12:251.

Foster JG, Hess JL (1980). Responses of superoxide dismutase and glutathione reductase activities in cotton leaf tissue exposed to an atmosphere enriched in oxygen. Plant Physiol 66: 482-487.

Goyal A, Sharma V, Upadhyay N, Gill S, Sihag M (2014). Flax and flaxseed oil: an ancient medicine \&amp; modern functional food. J Food Sci Technol 51: 1633-1653.

Lowry OH, Rosebrough NJ, Farr AL, Randall RJ (1951). Protein measurement with the Folin phenol reagent. J Biol Chem 193: 265-275.

Maity P, Samanta S, Nandi AK, Sen IK, Paloi S, Acharya K, Islam SS (2014). Structure elucidation and antioxidant properties of a soluble $\beta$-d-glucan from mushroom Entoloma lividoalbum. Int J Biol Macromol 63: 140-149.

Marklund S, Marklund G (1974). Involvement of the superoxide anion radical in the autoxidation of pyrogallol and a convenient assay for superoxide dismutase. Eur J Biochem 47: 469-474.

Pal J, Ganguly S, Tahsin KS, Acharya K (2010). In vitro free radical scavenging activity of wild edible mushroom, Pleurotus squarrosulus (Mont.) Singer. Indian J Exp Biol 48: 1210-1218.

Prasad K (2000). Flaxseed: a source of hypocholesterolemic and antiatherogenic agents. Drug News Perspect 13: 99-104.

Prasad K (2009). Flaxseed and cardiovascular health. J Cardiovasc Pharmacol 54: 369-377.

Sairam RK, Saxena DC (2000). Oxidative stress and antioxidants in wheat genotypes: possible mechanism of water stress tolerance. J Agron Crop Sci 184: 55-61.

Savicka M, Skute N (2010). Effects of high temperature on malondialdehyde content, superoxide production and growth changes in wheat seedlings (Triticum aestivum L.). Ekologija 56: 26-33.

Taga MS, Miller EE, Pratt DE (1984). Chia seeds as a source of natural lipid antioxidants. J Am Oil Chem Soc 61: 928-931.

Turkoglu A, Duru ME, Mercan N, Kivrak I, Gezer K (2007). Antioxidant and antimicrobial activities of Laetiporus sulphureus (Bull.) Murrill. Food Chem 101: 267-273.

Wang L, Chen J, Thompson LU (2005). The inhibitory effect of flaxseed on the growth and metastasisof estrogen receptor negative human breast cancer xenograftsis attributed to both its lignan and oil components. Int J Cancer 116: 793-798.

Cite this article: Sadi G, Karabakan B, AAsım M (2017). Biochemical characterization of four different genotypes of Flax (Linum usitatissimum L.) seeds. Anatolian Journal of Botany 1(1): 12-17. 